\title{
Evaluation of Elicitors against Tomato Leaf Curl Disease (ToLCD) under field conditions
}

\author{
Puja Pandey*, R. G. Parmar and A. B. Brahmbhatt \\ Department of Plant Pathology, B. A. College of Agriculture, Anand Agricultural University, \\ Anand, Gujarat - 388 110, India \\ *Corresponding author
}

\section{A B S T R A C T}

\section{Keywords}

Tomato leaf curl, Elicitors, Disease incidence

Article Info

Accepted: 20 July 2020 Available Online: 10 August 2020
In the present investigation different chemical elicitors viz., dipotassium hydrogen sulphate $(400 \mathrm{mM})$, potassium sorbate $(7.5 \%)$, sorbic acid $(7.5 \%)$, salicyclic acid $(100 \mathrm{mM})$ and chitosan $(1 \%)$ and biological elicitors viz., Trichoderma spp. (0.6\%) and Pseudomonas spp. (0.5\%) were used for seedling root dip treatment to check their resistance developing efficacy against ToLCD. Significant maximum percent control over disease $(77.91 \%)$ was found in seedling root dip with salicylic acid $(0.1 \mathrm{mM})$ and foliar spray at 15 and 30 DAT followed by sorbic acid treatment @ 1.5\% i.e. $64.52 \%$. Whereas, treatments were almost at par with each other.

\section{Introduction}

In nature, plants are often simultaneously or sequentially attacked by numerous herbivorous insects and microbial pathogens (fungal, bacterial, and virus). In case of tomato crop, several biotic and abiotic factors are the major constraints in production of tomato in India. Among these viral diseases, tomato leaf curl disease (ToLCD) is devastating and causes significant yield loss under severe conditions. Tomato yellow leaf curl disease (TYLCD) has been a global constraint to tomato (Solanum lycopersicum) production since the 1980s (Moriones and Navas-Castillo (2000). Infected susceptible tomato plants show symptoms that include yellowing, curling and cupping of leaves, severe stunting and abortion of flowers and fruits, all of which can lead to yield reduction of up to $100 \%$ (Abhary et al., 2007). The investigation of plant response to elicitors and bio-control agents is one of the most rapidly developing areas in plant pathology.

Many non-biological factors, such as salicylic acid (SA), benzothiadiazole (BTH), and methyl jasmonate (MeJA), have been reported to induce plant resistance (Eyre et al., 2006). Induced resistance includes induced systemic resistance (ISR) and systemic acquired resistance (SAR). It has been identified that 
the untranslatable messenger RNA (mRNA) of a PR protein can be converted into a translatable state through the exogenous application of SA to tobacco (Matsuoka et al., 1986). Moreover, SA can regulate the ROS levels in plants by controlling the activity of protective enzymes and avoiding or eliminating the plant cell damage caused by oxygen stress. In tomato, the exogenous application of SA can increase phenylalanine ammonia lyase (PAL) and POD activities and induce and enhance tomato plant resistance to Fusarium oxysporum f. sp. Lycopersici (Mandal et al., 2009).

Controlling TYLCV is difficult and is mainly based on intensive insecticide treatments that are used to control the vector populations (Palumbo et al., 2001). However, this method is harmful to the environment (Navot et al., 1991) and has limited success because it selects for insecticide-resistant populations in B. tabaci (Cahill et al., 1996; Elbert and Nauen, 2000). The best way to manage TYLCV is to enhance host plant resistance against this virus. Among synthetic chemical inducers, salicylic, sorbic and benzoic acids have been found to be active as antimicrobial agents in various trials as disease resistance inducers. Also, they have been reported for inducing resistance against several plant pathogens (Abdel-Kader, et al., 2012).

In the present investigation different biological and chemical elicitors have been used to check their resistance developing efficacy against TYLCD.

\section{Materials and Methods}

Present investigation was carried in polyhouse at the Department Plant Pathology and experimental farm, B. A. College of Agriculture, Anand Agricultural University, Anand.

\section{Raising of tomato nursery}

Tomato seedlings of variety AT -3 were raised in nursery under protected condition.

\section{Seedling root dip treatment followed by transplanting}

Chemical elicitors viz., dipotassium hydrogen sulphate $(400 \mathrm{mM})$, potassium sorbate (7.5\%), sorbic acid (7.5\%), salicyclic acid $(100 \mathrm{mM})$ and chitosan $(1 \%)$ and biological elicitors viz., Trichoderma spp. (0.6\%) and Pseudomonas spp. (0.5\%) were used for seedling root dip treatment for $2 \mathrm{hrs}$ and 30 min respectively before transplanting (Table 1). Untreated check was also maintained. But some treatments viz. salicylic acid $(100 \mathrm{mM})$, sorbic acid@75 g/L and potassium sorbate @ $75 \mathrm{~g} / \mathrm{L}$ were found to be toxic at their respective concentration as it lead to death of seedlings.

Hence, retransplanting was done after treating the seedlings at lower concentration. New treatment that were tested is as follows:

1. $\mathrm{T}_{4}$ (Salicylic acid): 0.1mM (@0.14 mg/L water)

2. $\mathrm{T}_{7}$ (Sorbic acid): 1.5\% (@ $15 \mathrm{~g} / \mathrm{L}$ water)

3. $\mathrm{T}_{8}$ (Potassium sorbate): 1.5\% (@ $15 \mathrm{~g} / \mathrm{L}$ water)*

* Still this treatment was found toxic.

\section{Foliar application in field}

Two foliar spray with dipotassium hydrogen sulphate $(400 \mathrm{mM})$, potassium sorbate $(1.5 \%)$, sorbic acid (1.5\%), salicyclic acid $(0.1 \mathrm{mM})$ and chitosan $(1 \%)$ and biological elicitors viz., Trichoderma spp. (0.6\%) and Pseudomonas spp. (0.5\%) was done at 15 and 30 days after transplanting. 


\section{Disease incidence}

Disease incidence was recorded as the number of root rot diseased plants relative to the number of planted seedlings in each treatment.

$$
\text { DI }=\frac{\text { No. of infected plants }}{\text { Total no. of plant assessed }} \times 100
$$

\section{Results and Discussion}

This experiment was conducted to evaluate the different biological and chemical plant resistance inducers against tomato leaf curl disease (ToLCV) under field conditions.

\section{After transplanting}

The data presented in the table 2 indicated that treatments viz., salicylic acid @ $100 \mathrm{mM}$, sorbic acid @ $7.5 \%$ and potassium sorbate @ $7.5 \%$ were found to be toxic to seedling. Hence, further retransplanting was done after lowering the dose of these treatment viz. salicylic acid@0.1mM (0.014 mg/L water), Sorbic acid@1.5\% (15 g/L water) and Potassium sorbate @ 1.5\% (15 g/L water).

\section{Before first spray}

The disease incidence was found significantly lower $(0.37 \%)$ in the treatment salicylic acid $(0.1 \mathrm{mM})$ which was at par with sorbic acid $(1.5 \%)$ treatment i.e. 0.45 per cent. Other treatments were found to be significantly less effective than salicylic acid and sorbic acid treatment but almost found at par with each other, showing minimum disease incidence over control.

\section{First spray}

Disease incidence was recorded at 7 days and 15 days after first spray and it was recoded that in the pooled data of both observations, the disease incidence was found significantly lower $(4.55 \%)$ in the treatment of salicylic acid $(0.1 \mathrm{mM})$ which was at par with sorbic acid $(1.5 \%)$ treatment i.e. 6.53 per cent.

Other treatments were found to be significantly less effective than salicylic acid and sorbic acid treatment but found at par with each other, showing minimum disease incidence over the control.

Table.1 Treatment details

\begin{tabular}{|c|c|}
\hline Sr. No. & Treatment details \\
\hline $\mathbf{T}_{1}$ & $\begin{array}{l}\text { Seedling root dip in formulation of Pseudomonas fluorescens }\left(1 \times 10^{8} \mathrm{cfu} / \mathrm{ml}\right) \text { WP } 1 \% \text { @ } 0.5 \% \text { followed by foliar spray at } 15 \\
\text { and } 30 \text { DAT }\end{array}$ \\
\hline $\mathbf{T}_{2}$ & $\begin{array}{l}\text { Seedling root dip in formulation of Trichoderma asperellum }\left(2 \times 10^{6} \mathrm{cfu} / \mathrm{ml}\right) \text { WP } 1 \% \text { @ } 0.6 \% \text { followed by foliar spray at } 15 \\
\text { and } 30 \text { DAT }\end{array}$ \\
\hline $\mathbf{T}_{3}$ & $\begin{array}{l}\text { Seedling root dip in formulation of Trichoderma viride }\left(2 \times 10^{6} \mathrm{cfu} / \mathrm{ml}\right) \text { WP } 1 \% \text { @ } 0.6 \% \text { followed by foliar spray at } 15 \text { and } 30 \\
\text { DAT }\end{array}$ \\
\hline $\mathbf{T}_{4}$ & Seedling root dip in salicylic acid $(0.1 \mathrm{mM}) @ 0.14 \mathrm{mg} / \mathrm{L}$ followed by foliar spray $(25 \mathrm{mM}) @ 3.45 \mathrm{~g} / \mathrm{L}$ at 15 and $30 \mathrm{DAT}$ \\
\hline $\mathbf{T}_{5}$ & Seedling root dip in chitosan WP 4\% @ 1g/L followed by foliar spray at 15 and 30 DAT \\
\hline $\mathbf{T}_{6}$ & $\begin{array}{l}\text { Seedling root dip in dipotassium hydrogen phosphate WP }(100 \mathrm{mM}) @ 17.42 \mathrm{~g} / \mathrm{L} \text { followed by foliar spray }(100 \mathrm{mM}) @ \\
17.42 \mathrm{~g} / \mathrm{L} \text { at } 15 \text { and } 30 \text { DAT }\end{array}$ \\
\hline $\mathbf{T}_{7}$ & Seedling root dip in sorbic acid @ $15 \mathrm{~g} / \mathrm{L}$ followed by foliar spray @ $25 \mathrm{~g} / \mathrm{L}$ at 15 and 30 DAT \\
\hline $\mathbf{T}_{8}$ & Seedling root dip in potassium sorbate @ $15 \mathrm{~g} / \mathrm{L}$ followed by foliar spray @ $25 \mathrm{~g} / \mathrm{L}$ at 15 and 30 DAT \\
\hline $\mathbf{T}_{9}$ & Chemical control (Acetamiprid 20 SP @ of 2g/10L) \\
\hline $\mathbf{T}_{10}$ & Control (Untreated) \\
\hline
\end{tabular}


Table.2 Evaluation of different chemical and biological plant resistance inducers against tomato leaf curl disease (ToLCD) under field conditions, depicting plant disease incidence

\begin{tabular}{|c|c|c|c|c|c|c|c|c|c|c|}
\hline \multirow{3}{*}{$\begin{array}{l}\text { Sr. } \\
\text { No. }\end{array}$} & \multirow[t]{3}{*}{ Treatments } & \multicolumn{7}{|c|}{ Percent disease incidence* } & \multirow{3}{*}{$\begin{array}{l}\text { Pooled } \\
\text { over } \\
\text { period } \\
\text { and } \\
\text { sprays }\end{array}$} & \multirow{3}{*}{$\begin{array}{l}\text { Per cent } \\
\text { control } \\
\text { over } \\
\text { disease }\end{array}$} \\
\hline & & \multicolumn{4}{|c|}{$1^{\text {st }}$ spray } & \multicolumn{3}{|c|}{$2^{\text {nd }}$ spray } & & \\
\hline & & Before spray & $1^{\text {st }}$ week & $2^{\text {nd }}$ week & Pooled & $1^{\text {st }}$ week & $2^{\text {nd }}$ week & Pooled & & \\
\hline 2 & $\begin{array}{l}\text { Seedling root dip in formulation of Trichoderma } \\
\text { asperellum }\left(2 \times 10^{6} \mathrm{cfu} / \mathrm{ml}\right) \text { WP } 1 \% \text { @ } 0.6 \% \text { followed } \\
\text { by foliar spray at } 15 \text { and } 30 \text { DAT }\end{array}$ & $\begin{array}{l}18.37^{\mathrm{a}} \\
(9.93)\end{array}$ & $\begin{array}{l}28.33^{\mathrm{a}} \\
(22.52)\end{array}$ & $\begin{array}{l}35.61^{\mathrm{ab}} \\
(33.90)\end{array}$ & $\begin{array}{l}31.97^{\mathrm{abc}} \\
(28.03)\end{array}$ & $\begin{array}{l}38.01^{\mathrm{ab}} \\
(37.92)\end{array}$ & $\begin{array}{l}39.59^{\mathrm{bc}} \\
(40.61)\end{array}$ & $\begin{array}{c}38.8^{\mathrm{c}} \\
(39.26)\end{array}$ & $\begin{array}{l}35.38^{\mathrm{ab}} \\
(33.52)\end{array}$ & 16.36 \\
\hline 3 & $\begin{array}{l}\text { Seedling root dip in formulation of Trichoderma } \\
\text { viride }\left(2 \times 10^{6} \mathrm{cfu} / \mathrm{ml}\right) \text { WP } 1 \% @ 0.6 \% \text { followed by } \\
\text { foliar spray at } 15 \text { and } 30 \text { DAT }\end{array}$ & $\begin{array}{c}13.29^{\mathrm{ab}} \\
(5.28)\end{array}$ & $\begin{array}{l}29.13^{\mathrm{a}} \\
(23.70)\end{array}$ & $\begin{array}{l}37.96^{\mathrm{ab}} \\
(37.84)\end{array}$ & $\begin{array}{l}33.55^{\mathrm{ab}} \\
(30.54)\end{array}$ & $\begin{array}{l}39.51^{\mathrm{ab}} \\
(40.48)\end{array}$ & $\begin{array}{l}41.29^{\mathrm{ab}} \\
(43.54)\end{array}$ & $\begin{array}{c}40.4^{\mathrm{b}} \\
(42.01)\end{array}$ & $\begin{array}{l}36.97^{\mathrm{ab}} \\
(36.17)\end{array}$ & 9.75 \\
\hline 4 & $\begin{array}{l}\text { Seedling root dip in salicylic acid } 99-100 \%, \mathrm{CDH} \\
\text { product }(0.1 \mathrm{mM}) @ 0.014 \mathrm{mg} / \mathrm{L} \text { followed by foliar } \\
\text { spray }(0.1 \mathrm{mM}) @ 0.014 \mathrm{mg} / \mathrm{L} \text { at } 15 \text { and } 30 \text { DAT }\end{array}$ & $\begin{array}{l}3.48^{\mathrm{b}} \\
(0.37)\end{array}$ & $\begin{array}{l}7.68^{b} \\
(1.79)\end{array}$ & $\begin{array}{l}16.95^{\mathrm{d}} \\
(8.50)\end{array}$ & $\begin{array}{l}12.32^{\mathrm{e}} \\
(4.55)\end{array}$ & $\begin{array}{l}20.78^{\mathrm{d}} \\
(12.59)\end{array}$ & $\begin{array}{l}23.81^{\mathrm{e}} \\
(16.30)\end{array}$ & $\begin{array}{r}22.99^{\mathrm{g}} \\
(15.25)\end{array}$ & $\begin{array}{l}17.31^{\mathrm{c}} \\
(8.85)\end{array}$ & 77.91 \\
\hline 5 & $\begin{array}{l}\text { Seedling root dip in Chitosan WP 4\% @ } 1 \mathrm{~g} / \mathrm{L} \\
\text { followed by foliar spray at } 15 \text { and } 30 \text { DAT }\end{array}$ & $\begin{array}{l}10.86^{\mathrm{ab}} \\
(3.55)\end{array}$ & $\begin{array}{l}26.86^{\mathrm{a}} \\
(20.41)\end{array}$ & $\begin{array}{l}32.35^{\mathrm{ab}} \\
(28.63)\end{array}$ & $\begin{array}{l}29.61^{\text {cd }} \\
(24.41)\end{array}$ & $\begin{array}{l}34.84^{\mathrm{b}} \\
(32.64)\end{array}$ & $\begin{array}{l}36.45^{\mathrm{c}} \\
(35.30)\end{array}$ & $\begin{array}{l}35.64^{\mathrm{e}} \\
(33.95)\end{array}$ & $\begin{array}{l}32.63^{\mathrm{ab}} \\
(29.07)\end{array}$ & 27.47 \\
\hline 6 & $\begin{array}{l}\text { Seedling root dip in Dipotassium hydrogen phosphate } \\
\text { WP }(100 \mathrm{mM}) @ 69.68 \mathrm{~g} / \mathrm{L} \text { followed by foliar spray } \\
(100 \mathrm{mM}) @ 17.42 \mathrm{~g} / \mathrm{L} \text { at } 15 \text { and } 30 \text { DAT }\end{array}$ & $\begin{array}{c}10.56^{\mathrm{ab}} \\
(3.36)\end{array}$ & $\begin{array}{c}26.99^{\mathrm{a}} \\
(20.60)\end{array}$ & $\begin{array}{l}34.83^{\mathrm{ab}} \\
(32.62)\end{array}$ & $\begin{array}{l}30.91^{\mathrm{bcd}} \\
(26.39)\end{array}$ & $\begin{array}{c}36.83^{b} \\
(35.93)\end{array}$ & $\begin{array}{l}38.22^{\mathrm{bc}} \\
(38.28)\end{array}$ & $\begin{array}{c}37.53^{\mathrm{c}} \\
(37.11)\end{array}$ & $\begin{array}{l}34.22^{\mathrm{ab}} \\
(31.63)\end{array}$ & 21.08 \\
\hline 7 & $\begin{array}{l}\text { Seedling root dip in sorbic acid @ } 1.5 \%(15 \mathrm{~g} / \mathrm{L}) \\
\text { followed by foliar spray @ } 1.5 \%(15 \mathrm{~g} / \mathrm{L}) \text { at } 15 \text { and } \\
30 \text { DAT }\end{array}$ & $\begin{array}{c}3.84^{\mathrm{b}} \\
(0.45)\end{array}$ & $\begin{array}{l}6.75^{\mathrm{b}} \\
(1.38)\end{array}$ & $\begin{array}{c}22.85^{\mathrm{c}} \\
(15.08)\end{array}$ & $\begin{array}{c}14.8^{\mathrm{e}} \\
(6.53)\end{array}$ & $\begin{array}{l}28.39^{c} \\
(22.61)\end{array}$ & $\begin{array}{l}30.63^{\mathrm{d}} \\
(25.96)\end{array}$ & $\begin{array}{l}29.51^{\mathrm{f}} \\
(24.26)\end{array}$ & $\begin{array}{c}22.15^{\mathrm{c}} \\
(14.22)\end{array}$ & 64.52 \\
\hline 8 & Chemical control (Acetamiprid 20 SP @ of 2g/10L) & $\begin{array}{c}20.89^{\mathrm{a}} \\
(12.71)\end{array}$ & $\begin{array}{c}24.89^{\mathrm{a}} \\
(17.71)\end{array}$ & $\begin{array}{l}31.86^{\mathrm{b}} \\
(27.86)\end{array}$ & $\begin{array}{l}28.37^{\mathrm{d}} \\
(22.58)\end{array}$ & $\begin{array}{l}34.81^{\mathrm{b}} \\
(32.59)\end{array}$ & $\begin{array}{l}37.04^{\mathrm{c}} \\
(36.29)\end{array}$ & $\begin{array}{l}35.93^{\mathrm{de}} \\
(34.43)\end{array}$ & $\begin{array}{l}32.15^{\mathrm{b}} \\
(28.32)\end{array}$ & 29.34 \\
\hline 9 & Control (Untreated) & $\begin{array}{c}21.9^{\mathrm{a}} \\
(13.91)\end{array}$ & $\begin{array}{l}30.80^{\mathrm{a}} \\
(26.22)\end{array}$ & $\begin{array}{l}38.42^{\mathrm{a}} \\
(38.62)\end{array}$ & $\begin{array}{l}34.61^{\mathrm{a}} \\
(32.26)\end{array}$ & $\begin{array}{l}43.06^{\mathrm{a}} \\
(46.62)\end{array}$ & $\begin{array}{l}44.79^{\mathrm{a}} \\
(46.62)\end{array}$ & $\begin{array}{l}43.93^{\mathrm{a}} \\
(48.13)\end{array}$ & $\begin{array}{c}39.28^{\mathrm{a}} \\
(40.08)\end{array}$ & - \\
\hline \multicolumn{2}{|c|}{ C. V. \% } & 49.15 & 27.63 & 10.43 & 18.45 & 7.96 & 5.48 & 6.58 & 12.56 & 9.71 \\
\hline
\end{tabular}

Note: Values outside parenthesis are $\sqrt{x+1}$ transformed values while, figures in the parenthesis are original values; Treatment means with the letter (s) in common are not significant by DNMRT at $5 \%$ level of significance. 
Fig.1 AUDPC ('A' value) and apparent rate of infection ('r' value)

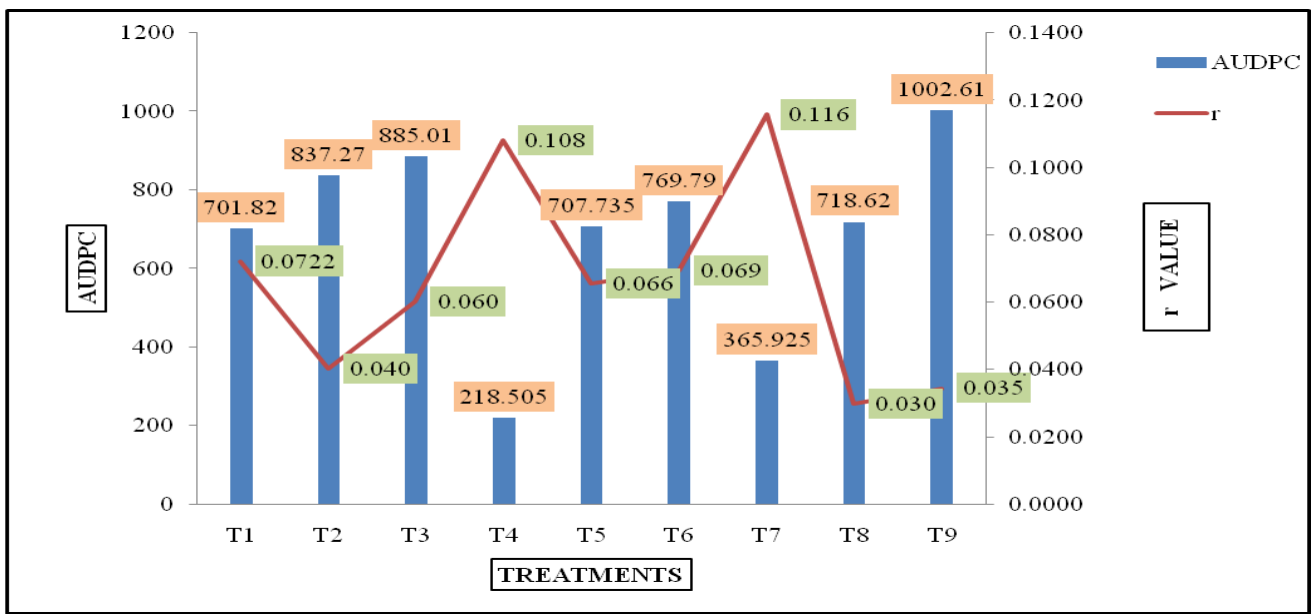

\section{Second spray}

Disease incidence was recorded at 7 days and 15 days after second spray and it recoded that in the pooled data of both observations, the disease incidence was found significantly lower $(15.25 \%)$ in the treatment salicylic acid $(0.1 \mathrm{mM})$ which was at par with sorbic acid $(1.5 \%)$ treatment i.e. 24.26 per cent. Other treatments were found to be significantly less effective than salicylic acid and sorbic acid treatment but almost at par with each other, showing minimum disease incidence with respect to control.

\section{Percent control over disease from pooled data of both the sprays}

Significant maximum percent control over disease $(77.91 \%)$ was found in case of seedling root dip in salicylic acid $(0.1 \mathrm{mM})$ followed by foliar spray at 15 and 30 DAT followed by sorbic acid treatment @ 1.5\% i.e. $64.52 \%$. Other treatments were found at par with each other (Table 2).

AUDPC ('A' value) and apparent rate of infection (' $r$ ' value)

The AUDPC values differed considerably for different treatments. ' $A$ ' value was found minimum in $\mathrm{T}_{4}$ (218.505) with infection rate of 0.108 followed by $\mathrm{T}_{7}$ (365.925) with 0.116 rate of infection. The maximum AUDPC (1002.61) was recorded in control with infection rate of 0.035 (Fig. 1).

Several studies have demonstrated the efficacy of exogenous application of SA analogue (BTH) for controlling fungal and bacterial diseases (Siegrist et al., 1997; Cole 1999), the effect of which is in the form of induced resistance. However, induced resistance to viruses through exogenous application of SA or its functional analogue has been demonstrated in only few studies. The resistance of tobacco to subsequent infection of TMV is found to be enhanced by pre-treatment of plants with aspirin or SA (White, 1979). Ong and Cruz (2016) reported that exogenous application of SA can delay the development and reduce the severity of tomato leaf curl disease. At shorter induction time of $5 \mathrm{dbi}$, treatment with 50 and $250 \mu \mathrm{M}$ SA effectively reduced leaf curl infection compared with the untreated control, but the reduction was greater with treatment of higher concentration $(250 \mu \mathrm{M})$ than lower concentration $(50 \mu \mathrm{M})$. However, at longer induction time of 10 and $15 \mathrm{dbi}$, reduction of leaf curl infection was highest with treatment of $50 \mu \mathrm{M} \mathrm{SA}$. Overall, reduction in the 
severity of tomato leaf curl was consistent with treatment of $50 \mu \mathrm{M} \mathrm{SA}$ at 15 days before inoculation. Likewise, the application of $100 \mu \mathrm{M}$ BTH as a soil drench, 7 days before inoculation with $\mathrm{CMV}-\mathrm{Y}$, protected plants against the virus (Anfoka, 2000). SA is an endogenous signal for the activation of certain plant defense responses, including PR-gene expression and the consequent establishment of enhanced resistance (Klessig, 2000).

In conclusion the tomato leaf curl disease is one of the devastating diseases and has been reported to be associated with several begomoviruses, thus making breeding for resistance more challenging. The above results suggest that SA can enhance tomato plant resistance through systemic acquired resistance.

\section{References}

Abdel-Kader, M.M., El-Mougy, N.S., ElGammal, N.G., Abd-El-Kareem, F., and Abd-Alla M.A. (2012). Laboratory evaluation of some chemicals affecting pathogenic fungal growth. J. Appl. Sci. Res. 8: 523-530.

Abhary, M., Patil, B. L., and Fauquet, C. M. (2007). "Molecular biodiversity, taxonomy, and nomenclature of tomato yellow leaf curl-like viruses," in Tomato Yellow Leaf Curl Virus Disease: Management, Molecular Biology, Breeding for Resistance, ed. H. Czosnek (Dordrecht: Springer), 85118.

Anfoka, G.H. (2000). Benzo-(1, 2, 3)thiadiazole-7-carbothioic acid Smethyl ester induces systemic resistance in tomato (Lycopersicon esculentum Mill cv.Vollendung) to cucumber mosaic virus. Crop Protection 19: 401-405.

Cahill, M., Gorman, K., Day, S. and Denholm, I. (1996). Baseline determination and detection of resistance to imidacloprid in Bemisia tabaci (Homoptera: Aleyrodidae). Bull Entomol Res 86: 343-349.

Cole, D.L. (1999). The efficacy of acibenzolar-S-methyl, an inducer of systemic acquired resistance against bacterial and fungal diseases of tobacco. Crop Prot. 18:267-273.

Elbert, A. and Nauen, R. (2000). Resistance of Bemisia tabaci (Homoptera: Aleyrodidae) to insecticides in southern Spain with special reference to neonicotinoids. Pest Manag Sci 56: 60-64.

Eyre, J. X., Faragher, J. and Joyce, D. C. (2006). Effects of postharvest methyl jasmonate treatments against Botrytis cinerea on Geraldton waxflower (Chamelaucium uncinatum). Aust $J$ Exp Agr.; 46 (5):717-23.

Klessig, D.F. (2000). Nitric oxide and salicylic acid signaling in plant defense. Proc. Natl. Acad. Sci. USA. 97:8849-8855.

Mandal S, Mallick N. and Mitra A. (2009). Salicylic acid-induced resistance to Fusarium oxysporum f. sp. lycopersici in tomato. Plant Physiol Biochem.; 47(7):642-9.

Matsuoka, M. and Ohashi, Y. (1986). Induction of pathogenesis-related proteins in tobacco leaves. Plant Physiol.; 80(2): 505-10.

Moriones, E., and Navas-Castillo, J. (2000). Tomato yellow leaf curl virus, an emerging virus complex causing epidemics worldwide. Virus Res. 71, 123-134.

Navot N, Pichersky E., Zeidan, M. and Czosnek H. (1991). Tomato yellow leaf curl virus: a whitefly-transmitted geminivirus with a single genomic component. Virology 185: 151-161.

Ong, S. and Cruz, F. C. S. (2016). Effect of exogenous application of salicylic acid 
on the severity of tomato leaf curl disease. J. ISSAAS . 22 (1): 137-145.

Palumbo, J. C., Horowitz, A. R. and Prabhaker, N. (2001). Insecticidal control and resistance management for Bemisia tabaci. Crop Prot., 20: 739765.

Siegrist, J. D., Glenewinkel, C. K. and
Schmidtke, M. (1997). Chemically induced resistance in green bean against bacterial and fungal pathogens. J. Plant Dis. Prot. 104: 599-610.

White, R.F. (1979). Acetyl salicylic acid (aspirin) induces resistance in tobacco. Virology. 99: 410-412.

\section{How to cite this article:}

Puja Pandey, R. G. Parmar and Brahmbhatt, A. B. 2020. Evaluation of Elicitors against Tomato Leaf Curl Disease (ToLCD) under Field Conditions. Int.J.Curr.Microbiol.App.Sci. 9(08): 21912197. doi: https://doi.org/10.20546/ijcmas.2020.908.250 